\title{
Financial stress during medical residency training: an experience from Iran
}

This article was published in the following Dove Press journal:

Neuropsychiatric Disease and Treatment

25 February 2016

Number of times this article has been viewed

\author{
Mohammad Zamani' \\ Vahid Zamani ${ }^{2}$ \\ 'Student Research Committee, \\ Department of Medicine, ${ }^{2}$ Vice- \\ Chancellery for Health, Babol \\ University of Medical Sciences, \\ Babol, Iran
}

\section{Dear editor}

We have read with great interest the article by Abdulghani et al, ${ }^{1}$ in which they well documented the high prevalence of stress among the Saudi Arabian medical residents and its effects on their working efficacy and general physical health during the residency training. This important issue similarly applies in Iran. Previous surveys performed on the Iranian resident trainees revealed the increased levels of psychological and emotional disorders such as depression, anxiety, and stress among them. ${ }^{2-4}$

There are several stressors such as difficult patients, job dissatisfaction, and large number of exams, which can have negative effects on the mental health status of medical residents during their training programs. ${ }^{5,6}$ However, among the Iranian medical residents, financial problem is other most important concern that has been less discussed by the policy makers. In Iran, unfortunately, the monthly income of residents of all medical specialties is very inadequate and this forces them to think about another work besides studying for subsistence, ${ }^{7}$ whereas educational policies, like most of the countries, interdict residents from working out of their learning environment and this take many occupational opportunities from them. On the other hand, the health care reform that has been recently implemented in Iran is associated with increased referring of the patients and working pressure of the residents, without increasing their income. This problem is more considerable for residents of more stressful specialties such as general surgery, neurosurgery, and orthopedics.

Heavy workload and low income can provide serious stressful conditions for Iranian resident trainees and gradually this can be associated with burnout and dissatisfaction and have a serious negative effect on their professional functions. Therefore, it is necessary that Iranian authorities ordain the policies in order to improve the educational and financial status of residents during their residency programs, especially for more stressful specialties.

\section{Disclosure}

The authors report no conflicts of interest in this communication.

\section{References}

Correspondence: Mohammad Zamani Student Research Committee, Department of Medicine, Babol University of Medical Sciences, Ganjafrouz Street, Babol, Mazandaran 47I76-47745, Iran

Tel +989359493131

Email mzamani20@gmail.com
1. Abdulghani HM, Al-harbi MM, Irshad M. Stress and its association with working efficiency of junior doctors during three postgraduate residency training programs. Neuropsychiatr Dis Treat. 2015;11: 3023-3029.

2. Shariati M, Yunesian M, Vash JH. Mental health of medical students: a cross-sectional study in Tehran. Psychol Rep. 2007;100(2):346-354.

3. Khorvash F, Askari G, Vesal S, et al. Investigating the anxiety level in Iranian medical residents in 2010-2011. Int J Prev Med. 2013;4(Suppl 2):S318-S322. 
4. Assadi SM, Nakhaei MR, Najafi F, Fazel S. Mental health in three generations of Iranian medical students and doctors. Soc Psychiatry Psychiatr Epidemiol. 2007;42(1):57-60.

5. Jafari N, Loghmani A, Montazeri A. Mental health of medical students in different levels of training. Int J Prev Med. 2012;3(Suppl 1): S107-S112.

6. Abdulghani HM, Irshad M, Al Zunitan MA, et al. Prevalence of stress in junior doctors during their internship training: a cross-sectional study of three Saudi medical colleges' hospitals. Neuropsychiatr Dis Treat. 2014;10:1879-1886.
7. Aramesh K, Mohebbi M, Jessri M, Sanagou M. Measuring professionalism in residency training programs in Iran. Med Teach. 2009; 31(8):e356-e361. 


\section{Authors' reply}

Hamza Mohammad Abdulghani'

Mohammed Meteb Al-harbi ${ }^{2}$

Mohammad Irshad'

'Department of Medical Education, ${ }^{2}$ Department of Family and Community Medicine, College of Medicine, King Saud University, Riyadh, Kingdom of Saudi Arabia

Correspondence: Hamza Mohammad Abdulghani

Department of Medical Education, College of Medicine, King Saud University, PO Box 230 155, Riyadh I I 32 I, Kingdom of Saudi Arabia

Tel +966505442859

Email hamzaabg@gmail.com

\section{Dear editor}

We read with great pleasure the letter to the editor written by Mohammad Zamani and Vahid Zamani, and we thank them for their interest in our paper, which showed that high prevalence of stress among the Saudi Arabian medical residents and its effects on their working efficacy and general physical health during the residency training. ${ }^{1}$

Our response to the letter to the editor is as follows:

First, our study agreed the high prevalence of stress among the residency trainees and its effects on their working efficacy and general physical health with an Iranian study. ${ }^{2}$

Second, we appreciate the authors' concern regarding the financial problems of the Iranian residence trainees. We agree with the fact that poor financial status is associated with the stress, distress, and burnout. ${ }^{3,4}$ Conversely, financial status had no effect on the stress level of the resident physicians of tertiary care hospital of Saudi Arabia. ${ }^{5}$ Our study ${ }^{1}$ did not evaluate the financial status of newly graduated residency trainees, because residency training is mandatory criteria for the newly medical graduates to work as a specialist in the
Kingdom of Saudi Arabia. Also, the payment for the postgraduate candidates training is sponsored by the government and the physicians' income is optimal. ${ }^{6}$ Therefore, possibly the financial issue does not act as a stress factor. However, the satisfactory family income was protective factor for stress to the medical students and residency trainees, which has been shown in a local study. ${ }^{7}$ Therefore, physicians' income is an important factor, if there is an issue. The health and education authority must carefully look into the financial aspect of the resident physicians and trainees, which is an important remedial factor for such a serious condition in the future health care providers.

\section{Disclosure}

The authors report no conflicts of interest in this communication.

\section{References}

1. Abdulghani HM, Al-harbi MM, Irshad M. Stress and its association with working efficiency of junior doctors during three postgraduate residency training programs. Neuropsychiatr Dis Treat. 2015;11: 3023-3029.

2. Koochaki GM, Charkazi A, Hasanzadeh A, Saedani M, Qorbani M, Marjani A. Prevalence of stress among Iranian medical students a questionnaire survey. East Mediterr Health J. 2011;17:593-598.

3. Heins A, Keehn C. Financial crisis for medical students and residents Ann Emerg Med. 2003;41:733-735.

4. Shariati M, Yunesian M, Vash JH. Mental health of medical students: a cross-sectional study in Tehran. Psychol Rep. 2007;100:346-354.

5. Alosaimi FD, Alghamdi AH, Aladwani BS, Kazim SN, Almufleh AS. Work-related stress and stress-coping strategies in residents and administrative employees working in a tertiary care hospital in Saudi Arabia. J Taibah Univ Med Sci. 2015;19(3):135.

6. Al Jadid MS. Rehabilitation medicine in the Kingdom of Saudi Arabia. Saudi Med J. 2011;32:962-963.

7. El-Gilany AH, Amr M, Hammad S. Perceived stress among male medical students in Egypt and Saudi Arabia: effect of socio-demographic factors Ann Saudi Med. 2008;28:442-448

Dove Medical Press encourages responsible, free and frank academic debate. The content of the Neuropsychiatric Disease and Treatment 'letters to the editor' section does not necessarily represent the views of Dove Medical Press, its officers, agents, employees, related entities or the Neuropsychiatric Disease and Treatment editors. While all reasonable steps have been taken to confirm the content of each letter, Dove Medical Press accepts no liability in respect of the content of any letter, nor is it responsible for the content and accuracy of any letter to the editor.

\section{Publish your work in this journal}

Neuropsychiatric Disease and Treatment is an international, peerreviewed journal of clinical therapeutics and pharmacology focusing on concise rapid reporting of clinical or pre-clinical studies on a range of neuropsychiatric and neurological disorders. This journal is indexed on PubMed Central, the 'PsycINFO' database and CAS, and is the official journal of The International Neuropsychiatric Association (INA). The manuscript management system is completely online and includes a very quick and fair peer-review system, which is all easy to use. Visit http://www.dovepress.com/testimonials.php to read real quotes from published authors. 